\title{
Adenovirus transforming 19-kD $T$ antigen has an enhancer-dependent trans-activation function and relieves enhancer repression mediated by viral and cellular genes
}

\author{
K. Yoshida, ${ }^{1}$ L. Venkatesh, M. Kuppuswamy, and G. Chinnadurai \\ Institute for Molecular Virology, St. Louis University Medical Center, St. Louis, Missouri 63110 USA
}

\begin{abstract}
The adenovirus E1b region codes for two major tumor antigens of $19 \mathrm{kD}$ and $55 \mathrm{kD}$, which are important for cell transformation. Our results indicate that the $19-\mathrm{kD} \mathrm{T}$ antigen possesses two enhancer-regulatory functions. It can trans-activate enhancer-linked promoters and relieve enhancer repression mediated by viral and cellular repressors. The 19-kD activation function enhances expression from different promoters linked to SV40, Py, E1a, and immunoglobulin heavy-chain enhancers. Enhancer activation by the 19-kD protein appears to be cell type-specific, since the heavy-chain and SV40 enhancers were not trans-activated in myeloma cells whereas the same enhancers were trans-activated in fibroblasts. The $19-\mathrm{kD}$ enhancer activation function appears to be dominant over the enhancer repression function of $\mathrm{Ela}$, since in cells expressing the $19-\mathrm{kD}$ protein there is no significant repression despite a large increase in E1a expression. The 19-kD T antigen activates the Py enhancer in undifferentiated F9 cells indicating that the activation function of E1b masks enhancer repression by an "E1a-like" cellular gene product. The enhancer activation function of the 19-kD T antigen may be important for cell transformation and cell differentiation.
\end{abstract}

[Key Words: Enhancer activation; repression; derepression; transformation; differentiation]

Received May 13, 1987; revised version accepted July 8, 1987.

The adenovirus Elb region, which maps between map positions 4.5 and 11.5 on the viral genome, codes for two major tumor antigens of $19 \mathrm{kD}$ and $55 \mathrm{kD}$ (for review, see Sussenbach 1984). In addition to these two major proteins, other polypeptides as well as mRNAs that could potentially code for polypeptides related to the 55-kD $\mathrm{T}$ antigen have also been identified (Green et al. 1982; Anderson et al. 1984; Virtanen and Pettersson 1955). The $19-\mathrm{kD} \mathrm{T}$ antigen has been shown to play an important role in cell transformation in cooperation with the Ela region (Chinnadurai 1983; Mak and Mak 1983; Babiss et al. 1984; Logan et al. 1984; Subramanian et al. 1984; Takemori et al. 1984; Barker and Berk 1987). The 55-kD T antigen has also been shown to be important for transformation (Bernard et al. 1983; Logan et al. 1984; Barker and Berk 1987). However, the relative importance of these two E1b-coded proteins in the conversion of Ela-transformed cells to the fully transformed phenotype has not been fully elucidated.

To delineate the roles of the $19-\mathrm{kD}$ and $55-\mathrm{kD} \mathrm{T}$ antigens in cell transformation in cooperation with Ela, we have been performing a two-stage transformation

1Present Address: Department of Molecular Biology, Sapporo Medical College, Sapporo, Japan. assay, using baby rat kidney cells immortalized by Ela (E1a-BRK). For second-stage transformation, DNA segments coding for either the $19-\mathrm{kD}$ or the $55-\mathrm{kD} \mathrm{T}$ antigens were transfected, using the $n e o^{\mathrm{r}}$ marker coded from plasmid $\mathrm{pSV}_{2}$ neo as the dominant selection marker. During these studies, we observed that Ela-BRK cells were relatively refractile to $\mathrm{neo}^{+}$transformation by transfection of $\mathrm{pSV}_{2}$ neo alone. However, cotransfection of DNA fragments encoding the E1b region substantially increased the formation of $\mathrm{neO}^{+}$-resistant colonies in Ela-immortalized BRK cells. This observation, in light of the known role of Ela in repression of the activity of SV40 (Velcich and Ziff 1985), polyoma (Borelli et al. 1984), and immunoglobulin heavy-chain (Hen et al. 1985 ) enhancers, prompted us to examine the role of the Elb region in enhancing $\mathrm{neO}^{+}$transformation by $\mathrm{pSV}_{2}$ neo. These studies have revealed that the $19-\mathrm{kD}$ protein coded by the Elb region possesses novel enhancer-regulatory functions. The $19-\mathrm{kD}$ regulatory activities may be important for cell transformation.

Relatively little is known about enhancer regulation. The two adenovirus transforming genes Ela and E1b 19-kD T antigen appear to have opposite effects on enhancer-driven gene expression. The $19-\mathrm{kD}$ gene is rela- 
tively well characterized, and a large number of mutants are available in this region. This gene product will be an important tool to investigate enhancer regulation.

\section{Results}

Effect of $A d 7$ E1b T antigens on $p S V_{2}$ neo transformation of E1a-BRK cells

To study the roles of the E1b $19-\mathrm{kD}$ and $55-\mathrm{kD}$ tumor antigens of adenoviruses in transformation, we established several BRK cell lines immortalized and partially transformed by the left $4.5 \%$ of the Ad2 (group C) genome, which encodes the Ela proteins. We assayed conversion of Ela-immortalized cells to the fully transformed phenotype by transfection of Elb coding regions from different adenovirus serotypes and found that the Ad7 (group B) Elb region had the best transformation complementing activity (K. Yoshida and G. Chinnadurai, in prep.). Therefore, some of the initial experiments described here were carried out using plasmids that express the Ad7 E1b. In the two-step transformation assays, the E1b plasmids were cotransfected on Ela-immortalized cells using the neo resistance marker (Colbere-Garapin 1981; Southern and Berg 1982) expressed from $\mathrm{pSV}_{2}$ neo (Southern and Berg 1982), and the transfected cells were maintained under antibiotic G418 for positive selection of cells harboring the Elb sequences. During these studies, it was observed that E1a-BRK cells consistently yielded fewer neo ${ }^{+}$colonies (i.e., without Elb) than two spontaneously immortalized rat cell lines, CREF (Fisher et al. 1982) and 3Y1 (Kimura et al. 1975), that do not contain Ela (Table 1). We reasoned that this relative inhibition of $\mathrm{neO}^{+}$transformation of Ela-BRK cells may be due to the enhancer-dependent repression (see Borelli et al. 1984; Velcich and Ziff 1985) of the SV40 early promoter-enhancer elements contained in $\mathrm{pSV}_{2}$ neo. In accordance with this expectation, we also observed that when neo ${ }^{+}$expression was under the control of the HSV-tk promoter (which lacks elements analogous to other enhancers|, consistently greater numbers of $\mathrm{neO}^{+}$transformants were obtained in E1a-BRK cells than with $\mathrm{pSV}_{2}$ neo (data not shown). However, it was

Table 1. Effect of $A d 7$ E1b on neo $^{+}$transformation of E1a-BRK and spontaneously immortalized rat cells.

\begin{tabular}{lccr}
\hline & \multicolumn{3}{c}{ Number of colonies/dish } \\
\cline { 2 - 4 } potransfected & Ela-BRK & CREF & 3 Y1 \\
\hline pRA & 32 & 30 & 14 \\
pRA-N & 5 & 27 & 9 \\
pRA-A & 42 & 23 & 19 \\
pUC13 & 1 & 30 & 14 \\
\hline
\end{tabular}

a Average of two independent experiments. 60-mm dishes containing about $5 \times 10^{5}$ cells were transfected with $2 \mu \mathrm{g}$ of $\mathrm{pSV}_{2}$ neo and $8 \mu \mathrm{g}$ of either E1b plasmid or pUC13 vector DNA. About $24 \mathrm{hr}$ after transfection, cells in each dish were split into five dishes and subjected to G418 selection from $24 \mathrm{hr}$ after plating. surprising that cotransfection of pRA (RsaI-A fragment, N1431-4024), coding for the Ad7 E1b 55-kD and 19-kD $\mathrm{T}$ antigens, with $\mathrm{pSV}_{2}$ neo caused about 30 -fold stimulation in $\mathrm{neO}^{+}$colony formation in Ela-BRK cells and no such dramatic effects were observed with CREF and 3Y1 cells (Table 1). Similarly, cotransfection of a mutant plasmid, pRA-A (for description of various mutants, see Fig. 1 and Materials and methods|, capable of coding the entire 19-kD T antigen and only a severely truncated form of the 55-kD T antigen (amino-terminal 90 amino acids), also caused a large increase in neo ${ }^{+}$transformation of Ela-BRK cells. On the other hand, mutant pRA-N, capable of coding for the 55-kD T antigen but containing a mutation that abolishes the initiation codon for the $19-\mathrm{kD}$ T antigen, caused only a relatively modest increase in the frequency of $n e \mathrm{O}^{+}$transformation. In contrast to the effect of Elb on neo ${ }^{+}$expression in Ela-BRK cells, cotransfection of the various Elb plasmids with $\mathrm{pSV}_{2}$ neo did not have any significant effect on the frequency of induction of $n e o^{+}$transformants in the spontaneously transformed rat cell lines, CREF and 3Y1. It would appear that the level of neo expression directed by $\mathrm{pSV}_{2}$ neo alone in the cell lines is sufficient to ensure maximal frequency of $\mathrm{ne}^{+}$colony induction; further increases in neo expression, such as that evidenced upon cotransfection of the 19-kD T antigen (see below), do not result in increased neo ${ }^{+}$transformation rates in CREF and $3 \mathrm{Y} 1$ cells. These results suggest that the 19-kD T antigen coded by the E1b region of Ad7 has a stimulatory role in the $\mathrm{neO}^{+}$transformation of $\mathrm{Ad} 2$ Ela-expressing cells when neo expression is under the transcriptional control of SV40 promoter-enhancer elements.

\section{Effect of Ad7 E1b on SV40 early promoter activity in E1a-BRK cells}

The observation that the Ad7 Elb 19-kD T antigen caused a substantial increase in the frequency of neo transformation of Ela-BRK cells prompted us to examine the effect of $\mathrm{Ad} 7 \mathrm{E} 1 \mathrm{~b}$ on the expression of $\mathrm{pSV}_{2}$ neo in these cells. To study the effect of Elb T antigens, $\mathrm{pSV}_{2}$ neo was cotransfected with different E1b plasmids on two different Ela-BRK cell lines (Ela-BRK-1 and E1a-BRK-2); total cytoplasmic RNA was extracted $48 \mathrm{hr}$ after transfection and subjected to S1 nuclease analysis. Results obtained with the E1a-BRK-1 cell line are shown in Figure 2A. In E1a-BRK-1 cells transfected with $\mathrm{pSV}_{2}$ neo and $\mathrm{pRA}-\mathrm{NA}$ defective in both the $19-\mathrm{kD}$ and $55-\mathrm{kD} T$ antigens, there was a very low level of neo expression. However, in cells cotransfected with $\mathrm{pSV}_{2}$ neo and pRA (wt E1b) or pRA-A (defective in the $55-\mathrm{kD} \mathrm{T}$ antigen), a significant amount of the 390-nucleotide S1 nuclease-protected DNA fragment specific for the neo probe was observed. In contrast, cells cotransfected with $\mathrm{pRA}-\mathrm{N}$, expressing only the $55-\mathrm{kD} \mathrm{T}$ antigen, contained very low amounts of neo-specific RNA, as in the case of pRA-NA. Semiquantitative estimation of the intensity of the S1-protected DNA fragments revealed that the levels of $\mathrm{pSV}_{2}$ neo expression induced by pRA or pRA-A were about 10-15 times greater 


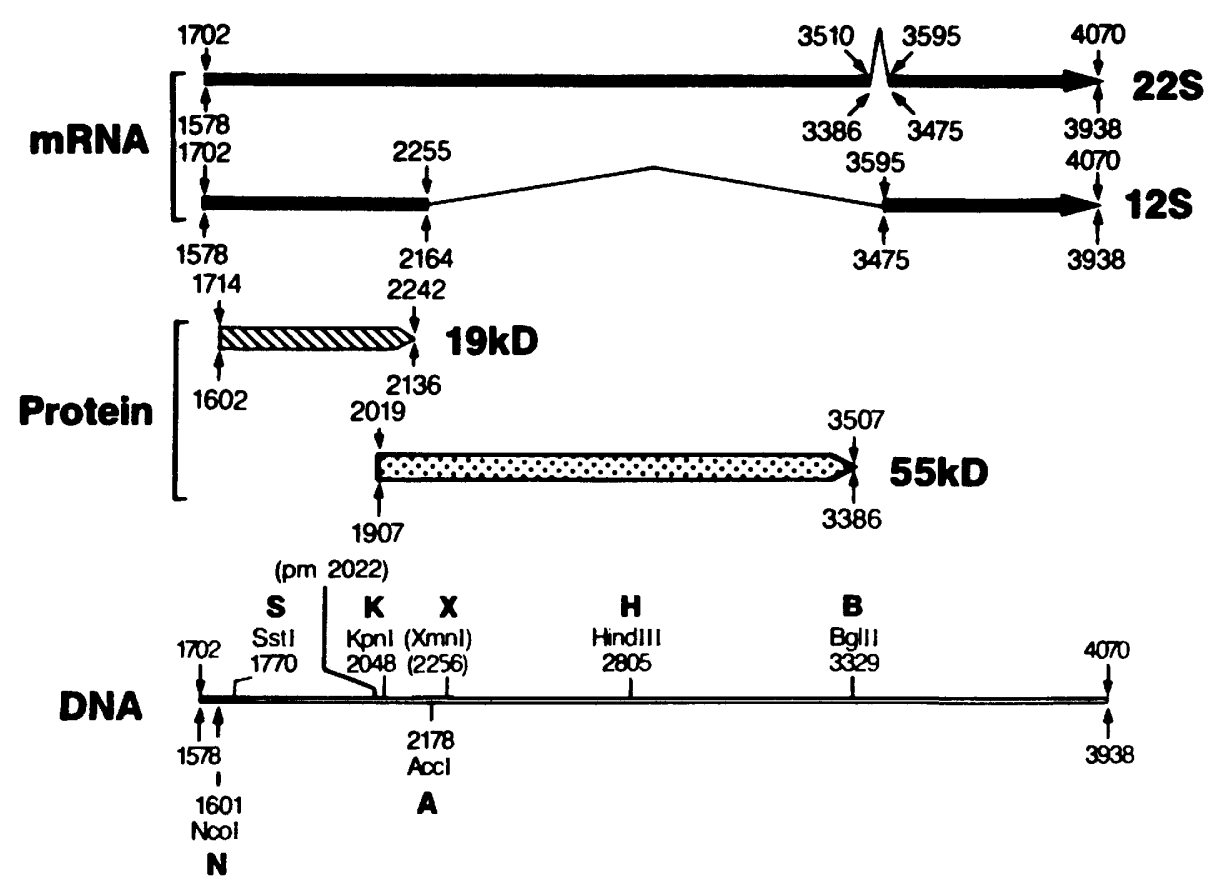

Figure 1. Organization of the group C (Ad2 and Ad5) and group B (Ad7) adenovirus E1b regions. This figure is based on Bos et al. (1981) and Dijkema et al. (1982) as summarized by Sussenbauch (1984). Only the major mRNAs and proteins are indicated. The mutations at various restriction sites are indicated as follows: $(\mathrm{H})$ HindIII; (S) SstI; (K) KpnI; (X) XmnI; (B) BgIII; (N) NcoI; and (A) AccI. (pm2022) Point mutation at position 2022 (Barker and Berk 1987) on the Ad2 genome. The Ad2 and Ad5 coordinates are given on the top and the Ad7 coordinates are given at the bottom of each diagram. The Ad2 coordinates are given within parentheses.

than the levels induced by pRA-NA or pRA-N in four separate experiments. Similar results were also obtained with the E1a-BRK-2 cell line (results not shown). These results suggest that the very low levels of neo ${ }^{+}$transformation of Ela-BRK cells may be due to the poor expression of $\mathrm{pSV}_{2}$ neo in these cells. The level of $\mathrm{pSV}_{2}$ neo expression and $\mathrm{neo}^{+}$transformation of Ela-BRK cells can be increased by cotransfection of Ad7 Elb plasmids coding for functional $19-\mathrm{kD}$ T antigen.

The effect of Ad7 E1b T antigens on the expression of another test gene coding for chloramphenicol acetyl transferase (CAT) under the control of the SV40 early promoter-enhancer elements in the plasmid $\mathrm{pSV}_{2} \mathrm{CAT}$ (Gorman et al. 1982) was also tested on Ela-BRK-1 cells (Fig. 2B). Cotransfection of $\mathrm{pSV}_{2} \mathrm{CAT}$ with pRA or pRA-A caused about five- to eightfold increase in CAT activity compared to cells cotransfected with $\mathrm{pSV}_{2} \mathrm{CAT}$ and pRA-N or pRA-NA. Similar results were also obtained with comparable Ad5 wt or mutant E1b plasmids (not shown). These results on CAT expression are in very good agreement with the results on neo expression and indicate that the $\mathrm{Ad} 7 \mathrm{E} 1 \mathrm{~b} 19-\mathrm{kD} \mathrm{T}$ antigen induces substantial stimulation of expression from the SV40 early promoter in E1a-expressing BRK cells.

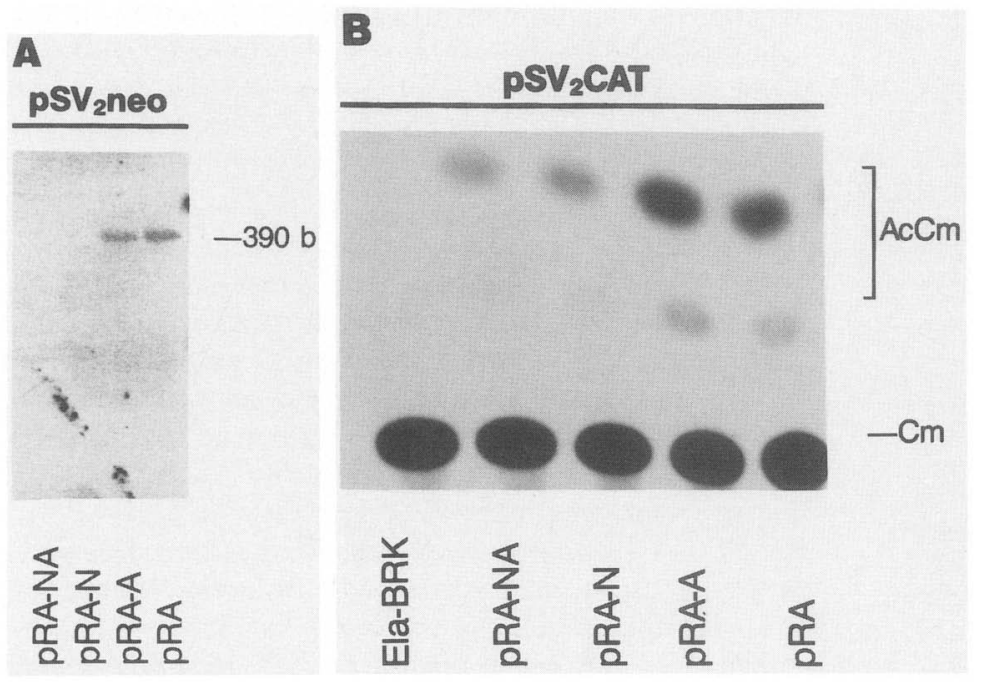

Figure 2. Effect of Ad7 Elb T antigens on SV40 early promoter expression in Ela-BRK cells. $(A) \mathrm{Ex}$ pression of $\mathrm{pSV}_{2}$ neo. Ela-BRK-1 cells were cotransfected with $5 \mu \mathrm{g}$ of $\mathrm{pSV}_{2}$ neo and $5 \mu \mathrm{g}$ of the various Elb plasmids (Wigler et al. 1979). Total cytoplasmic RNA was extracted $48 \mathrm{hr}$ after transfection, treated with $50 \mathrm{U} / \mathrm{ml}$ RQ1 DNase (Promega Biotec), and analyzed by quantitative $S 1$ nuclease method as described (Hurwitz and Chinnadurai 1985). A 1883-bp fragment (BglII-PstI) 5'-end-labeled at the BglII site, located within the neo sequences of $\mathrm{pSV}_{2}$ neo, was used as the probe. $(B)$ Expression of $\mathrm{pSV}_{2} \mathrm{CAT}$. ElaBRK-1 cells were transfected with $\mathrm{pSV}_{2} \mathrm{CAT}$ and the various Elb plasmids as in $A$. CAT activity was determined from the extracts prepared $48 \mathrm{hr}$ after transfection as described by Gorman et al. (1982). (AcCm) Acetyl chloramphenicol; (Cm) chloramphenicol. 


\section{Lack of E1a-mediated repression in the presence of $E 1 b$}

The initial observations with Ad7 E1b T antigens were further extended using the Ela and Elb genes of Ad5 in transient assays in rat or human cells that do not contain Ela. This system also facilitates a more direct assay of the Elb effect on Ela-mediated repression of $\mathrm{pSV}_{2}$ neo. Plasmids containing the $\mathrm{E} 1 \mathrm{a}$ and $w t \mathrm{E} 1 \mathrm{~b}$ coding sequences of Ad5 (pXC, mp 0-15.0, XhoI-C fragment) or E1a and various E1b mutations (illustrated in Fig. 1 and described under Materials and methods) were cotransfected with $\mathrm{pSV}_{2}$ neo on the rat fibroblast cell line CREF or human HeLa cells, and neo-specific RNA was analyzed $48 \mathrm{hr}$ after transfection. The results on CREF cells are shown in Figure 3A; similar results were also observed with HeLa cells. In cells cotransfected with $\mathrm{pSV}_{2}$ neo and pUC13 vector DNA, there was significant synthesis of neo RNA. However, in cells cotransfected with $\mathrm{pSV}_{2}$ neo and $\mathrm{pXC}-\mathrm{K}$ (mutated at the $\mathrm{KpnI}$ site at position 2048 and expressing functional Ela but defective in both $\mathrm{E} 1 \mathrm{~b} \mathrm{~T}$ antigens), expression of neo was greatly reduced compared to the cells that did not receive E1a (i.e., transfected with pUC13). This is expected

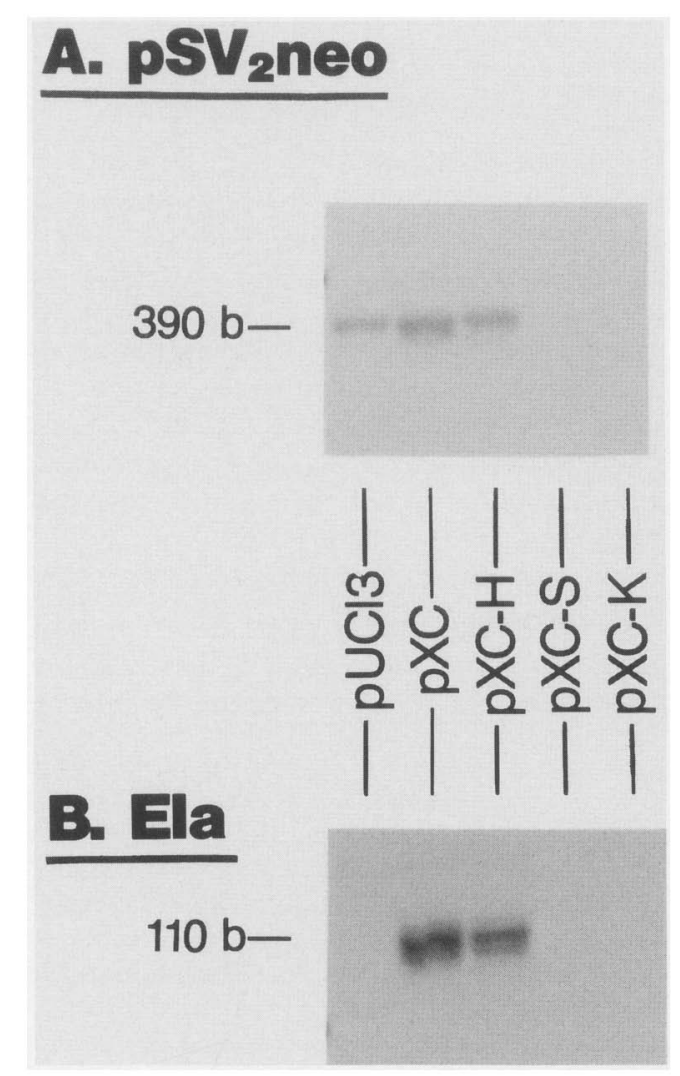

Figure 3. Effect of Ad5 Elb T antigens on Ela-mediated repression of SV40 promoter. CREF cells were transfected with 5 $\mu \mathrm{g}$ of $\mathrm{pSV}_{2}$ neo and $10 \mu \mathrm{g}$ of pUC13 or pXC or its mutant derivates. $(A)$ Total cytoplasmic RNA was analyzed for neo expression as described under Fig. 2. $(B)$ Ela expression was analyzed in the same RNA samples by including an Ela probe $5^{\prime}$-end-labeled at nucleotide position 1343 (XbaI site). The Ela probe (XbaI-EcoRI) was prepared from plasmid pLAl $\Delta \mathrm{b}$. since it has been known that Ela represses the SV40 promoter activity (Velcich and Ziff 1985). In cells cotransfected with pXC-S (mutated at the SstI site at position 1770), which expresses E1a and the E1b 55-kD T antigen but not the 19-kD T antigen, the level of neo expression was also very low and similar to that in cells transfected with $\mathrm{pSV}_{2}$ neo and $\mathrm{pXC}-\mathrm{K}$. However, in cells cotransfected with $\mathrm{pSV}_{2}$ neo and wt $\mathrm{pXC}$ or $\mathrm{pXC}-\mathrm{H}$, which contains a mutation in the $55-\mathrm{kD} \mathrm{T}$ antigen coding region (at the HindIII site at position 2805), there was a substantial increase in neo expression, indicating that $\mathrm{Ela}$ mediated repression of SV40 early promoter activity is not observed in the presence of the amino-terminal half of Elb. An enhancerless $\beta$-globin plasmid, pG2, was cotransfected in these experiments as a control for normalizing transfection efficiencies, which did not vary by more than $10 \%$. Since the pXC-S mutation specifically affecting the $19-\mathrm{kD} \mathrm{T}$ antigen did not cause stimulation of neo expression compared with cells transfected with pXC-K, expressing only Ela, the Elb function that relieves Ela-mediated repression appears to be specific for the 19-kD T antigen. All these Elb mutants were observed to express comparable levels of Elb (see Fig. 4); therefore, the observed effect of pXC-S mutation may not be due to unusually unstable E1b RNA. It is also noteworthy that a comparable $\mathrm{Ad} 219-\mathrm{kD}$ mutation (dl250) with similar effects as pXC-S has been transferred to the viral genome and has been shown to induce Elb 55-kD and 55-kD-related proteins at levels comparable to that observed in $w t$ infected cells (see Subramanian et al. 1984).

\section{Enhanced E1a expression in the presence of E1b}

The RNA samples from cells transfected with $\mathrm{pSV}_{2}$ neo and the pXC-derived plasmids were also analyzed for expression of Ela (Fig. 3B). Cells transfected with wt pXC, expressing both $19-\mathrm{kD}$ and $55-\mathrm{kD}$ T antigens, or $\mathrm{pXC}-\mathrm{H}$, expressing the amino-terminal half of $\mathrm{E} 1 \mathrm{~b}$, contained substantially larger amounts of Ela-specific RNA than cells transfected with pXC-S (defective in the 19-kD T antigen) or $\mathrm{pXC}-\mathrm{K}$ (defective in both $19-\mathrm{kD}$ and $55-\mathrm{kD} \mathrm{T}$ antigens). These results indicate that the $\mathrm{E} 1 \mathrm{~b} 19-\mathrm{kD} \mathrm{T}$ antigen also has a pronounced effect on the expression of Ela. It is unlikely that the observed effect of E1b is due to any cis effects of the Elb region since we have also observed similar activation of Ela expression when the $\mathrm{Ela}$ and Elb sequences are present on two different plasmids (see Fig. 7).

\section{Transactivation of $p S V_{2}$ neo by $E 1 b$}

To determine whether the effect of the Elb 19-kD T antigen that we observed was due to any possible trans-activation function of its own, rather than due to the removal of repression by Ela, we constructed plasmids containing only Elb ( $\mathrm{p} \Delta \mathrm{XC}$ ) by removal of most of the Ela sequences including the promoter and enhancer regions. Since Ela has been shown to be required for efficient expression of other early genes (Berk et al. 1979; Jones and Shenk 1979|, some of the earlier experiments were carried out using plasmids expressing E1b under 


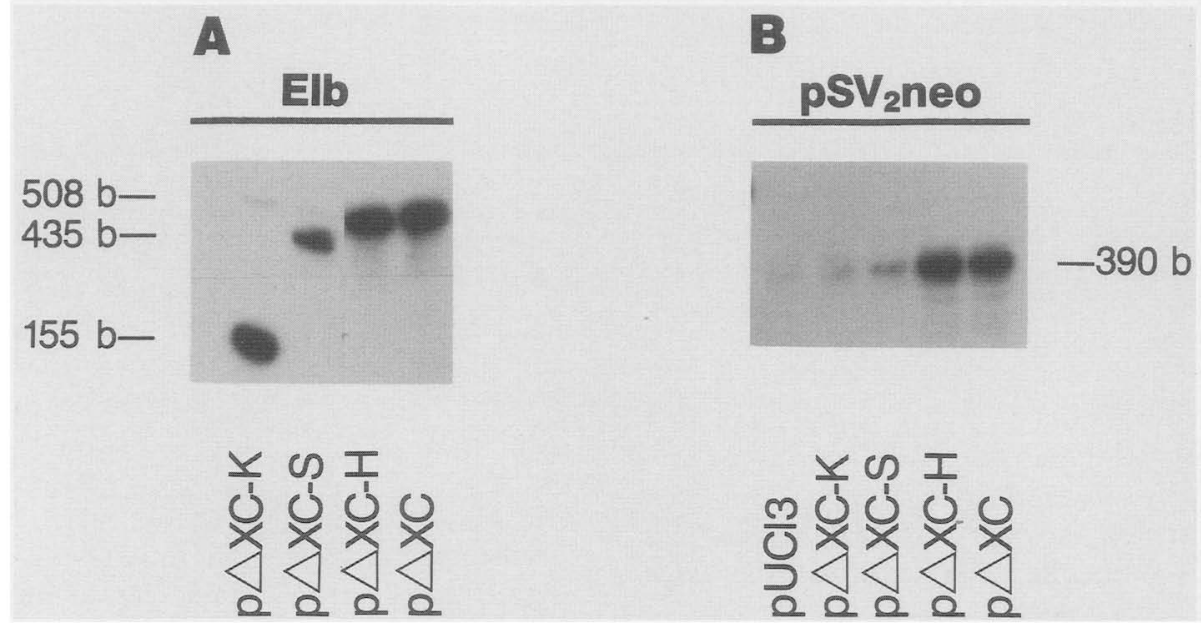

Figure 4. Trans-activation of $\mathrm{pSV}_{2}$ neo by $\mathrm{Ad} 5 \mathrm{E} 1 \mathrm{~b}$. $(A)$ Expression of $\mathrm{E} 1 \mathrm{~b}$ from $\mathrm{p} \Delta \mathrm{XC}$-derived plasmids was analyzed using a probe (XbaI-NcoI) 5'-end-labeled at position 2210 of the Ad5 genome (NcoI site). This probe was prepared from plasmid $\mathrm{p} \Delta \mathrm{XC}$. $(B)$ Trans-activation of $\mathrm{pSV}_{2}$ neo by various $\mathrm{p} \Delta \mathrm{XC}$-derived plasmids was analyzed as described under $A$.

the transcriptional control of MSV-LTR. However, in a number of subsequent experiments using both Ad5 and Ad7 Elb plasmids, we have observed that these plasmids can express significant amounts of Elb without transactivation by Ela. It is noteworthy that some of the earlier studies have also indicated that among the various adenovirus early genes, Elb is the least dependent on Ela (see Solnick and Anderson 1982). CREF or HeLa cells were cotransfected with $\mathrm{pSV}_{2}$ neo and wt $\mathrm{p} \Delta \mathrm{XC}$, expressing E1b but not Ela, or the various E1b mutant derivatives of $\mathrm{p} \Delta \mathrm{XC}$. The RNA from transfected cells was analyzed for $\mathrm{E} 1 \mathrm{~b}$ and neo expression. As seen in Figure 4A, the Elb-specific RNA (of expected sizes depending on the mutations) was efficiently expressed in cells transfected with the various $\mathrm{p} \Delta \mathrm{XC}$-derived plasmids, which do not contain E1a. In a number of different experiments, the levels of Elb expression from $\mathrm{p} \Delta \mathrm{XC}$-derived plasmids were slightly lower than the levels of expression from $\mathrm{pXC}$-derived plasmids (results not shown). When these RNA samples were analyzed for neo-specific RNA (Fig. 4B), cells transfected with $\mathrm{pSV}_{2}$ neo and pUC13 or $\mathrm{p} \Delta \mathrm{XC}-\mathrm{K}$ (defective in both Elb proteins) expressed reduced levels of neo RNA. In contrast, cells cotransfected with plasmids expressing wt $\mathrm{E} 1 \mathrm{~b}(\mathrm{p} \Delta \mathrm{XC})$ sequences or the amino-terminal half of $\mathrm{E} 1 \mathrm{~b}(\mathrm{p} \Delta \mathrm{XC}-\mathrm{H})$ expressed about 15- to 20-fold more neo RNA (as determined from three independent experiments), suggesting that the $\mathrm{E} 1 \mathrm{~b}$ region has a trans-activating function. Similar activation of neo expression was not observed in cells transfected with $\mathrm{p} \Delta \mathrm{XC}$-S /defective in $19-\mathrm{kD} T$ antigen), indicating that the $19-\mathrm{kD} \mathrm{T}$ antigen is essential for this trans-activation function.

\section{Effect on E1a-mediated repression of polyoma enhancer}

Since repression of the SV40 promoter-enhancer elements of $\mathrm{pSV}_{2}$ neo was not observed in the presence of $19-\mathrm{kD} \mathrm{T}$ antigen, we tested whether repression of the polyoma (Py) enhancer by Ela occurs in the presence of this protein. For this purpose, a plasmid construct,
pG2Py (Hen et al. 1986), expressing the rabbit $\beta$-globin gene under the control of $\beta$-globin promoter and Py enhancer, was cotransfected with pUCl3 or the various pXC-derived plasmids on CREF cells, and $\beta$-globin-specific cytoplasmic RNA was quantitated (Fig. 5A).

As expected, expression of $\beta$-globin was repressed in cells transfected with pG2Py and pXC-K (which expresses E1a and no functional E1b) by about three- to fivefold compared with cells cotransfected with pUC13. Similar low levels of globin were also expressed in cells cotransfected with pG2Py and pXC-S. However, cotransfection of pG2Py with wt $\mathrm{pXC}$ or $\mathrm{pXC}-\mathrm{H}$ increased globin expression to levels comparable to those observed in cells that do not express any Ela (lane pUC13), indicating that in the presence of the amino-terminal portion of the Elb region, Ela-mediated repression of Py enhancer is not evident. This release of repression was evident in four independent experiments. The fact that the mutation in the $19-\mathrm{kD} \mathrm{T}$ antigen coding region does not significantly alter the level of repression is indicative again of the $19-\mathrm{kD} \mathrm{T}$ antigen being essential in overcoming E1a-mediated repression of the Py enhancer.

\section{Trans-activation of Py enhancer-driven $\beta$-globin expression}

To determine whether Ela by itself can trans-activate the Py enhancer- $\beta$-globin promoter elements of pG2Py as in the case of $\mathrm{pSV}_{2}$ neo, we cotransfected pG2Py and the various E1b plasmids, and $\beta$-globin RNA expression was assayed (Fig. 5B). These results more or less paralleled the results obtained with $\mathrm{pSV}_{2}$ neo (see Fig. 4) again, revealing trans-activation of globin expression (by about four- to sixfold in four different experiments) by plasmids $\mathrm{p} \Delta \mathrm{XC}$ or $\mathrm{p} \Delta \mathrm{XC}-\mathrm{H}$, whereas plasmids $\mathrm{p} \Delta \mathrm{XC}-\mathrm{S}$ or $\mathrm{p} \Delta \mathrm{XC}-\mathrm{K}$ did not have any significant activation effect compared with pUC13. In some of these experiments, two additional Elb mutant plasmids were also tested. $\mathrm{p} \Delta \mathrm{XC}-\mathrm{XB}$, an Ad2-Ad5 E1b plasmid that retains the en- 


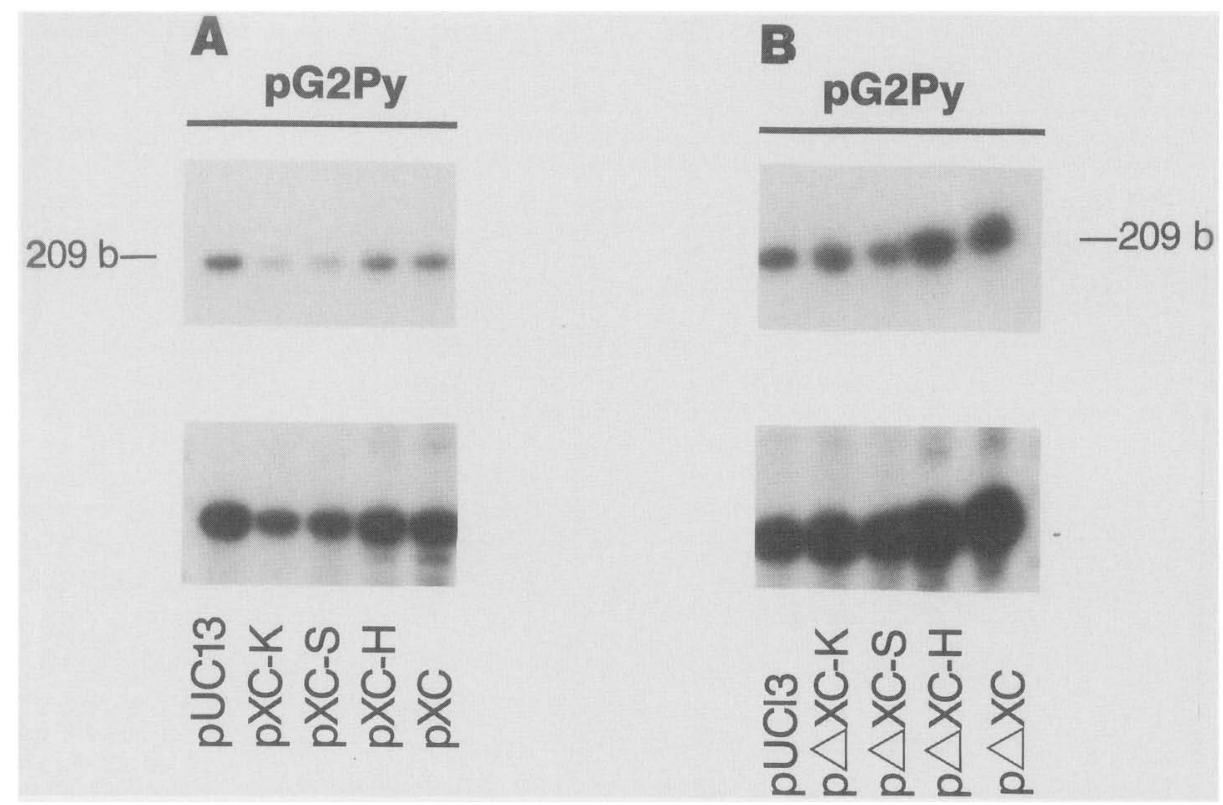

Figure 5. Effect of Ad5 E1b T antigens on pG2Py expression. CREF cells were cotransfected as described under Fig. 2 with pG2Py and $\mathrm{pXC}(A)$ or $\mathrm{p} \triangle \mathrm{XC}(B)$ derived plasmids, and globin expression was determined S1 nuclease analysis of total cytoplasmic RNA. A 5 '-end-labeled (at BamHI site) probe specific for the second exon of rabbit $\beta$-globin was prepared from plasmid pG2 (Hen et al. 1986) and used for the S1 analysis. The autoradiograms in the bottom panel are longer exposures of the top panels.

tire 19-kD $\mathrm{T}$ antigen coding region and deletes most of the $55-\mathrm{kD} \mathrm{T}$ antigen coding region from $\mathrm{N} 2256$ (Ad2, $X m n I$ site) to N3322 (Ad2, BglII site), and plasmid p19Kpm2022-X, which contains the $19-\mathrm{kD} \mathrm{T}$ antigen coding region (XbaI-XmnI site) and a point mutation that converts the third codon in the $55-\mathrm{kD} \mathrm{T}$ antigen reading frame into a nonsense codon (Barker and Berk 1987), were found to trans-activate pG2Py to a similar extent as $\mathrm{p} \Delta \mathrm{XC}-\mathrm{H}$ (data not shown). Mutant $\mathrm{p} \Delta \mathrm{XC}-\mathrm{XB}$ can only code for the amino-terminal 80 amino acids of the $55-\mathrm{kD} \mathrm{T}$ antigen, whereas plasmid p19Kpm2022-X can only code for two amino-terminal amino acids of the $55-\mathrm{kD}$ protein and is therefore almost totally defective in all the 55-kD-related proteins (see Virtanen and Petterson 1985). The use of these mutants further reinforces the results indicating that the $19-\mathrm{kD} \mathrm{T}$ antigen is essential for the trans-activation and derepression functions and suggests that the $55-\mathrm{kD} \mathrm{T}$ antigen may not have a significant role in these functions.

\section{Effect on immunoglobulin enhancer-driven CAT expression}

Since the experiments described in the preceding sections revealed that gene expression driven by SV40 (Fig. 4), Py (Fig. 5), and possibly Ela (Figs. 3 and 7) enhancers was activated by the $19-\mathrm{kD} \mathrm{T}$ antigen, we also tested whether the Elb region could trans-activate gene expression mediated by the immunoglobulin heavy-chain enhancer. For this purpose we used a test plasmid construct, pAcatH (Garcia et al. 1986) expressing the CAT gene under the minimal SV40 promoter (Laimins et al. 1982) and the heavy-chain enhancer. Plasmid pAcatH and the various Elb plasmids were cotransfected on the mouse myeloma cell line S194 (ATCC T1B-19), and CAT activity was determined.

As seen in Figure 6A, cotransfection of pAcatH with the wt Elb region $(\mathrm{p} \Delta \mathrm{XC})$ or plasmids expressing functional $19-\mathrm{kD} \mathrm{T}$ antigen $(\mathrm{p} \Delta \mathrm{XC}-\mathrm{H})$ or $55-\mathrm{kD} \mathrm{T}$ antigen ( $\mathrm{p} \Delta \mathrm{XC}$-S) had no significant effect on $\mathrm{pAcatH}$ expression compared with $\mathrm{p} \Delta \mathrm{XC}-\mathrm{K}$, which is defective in both $\mathrm{Elb}$ proteins. To determine whether Ela-mediated repression of the heavy-chain enhancer (Hen et al. 1985) could be overcome by Elb, pAcatH was cotransfected with pXC-derived plasmids, and CAT activity was determined (Fig. 6B). As expected, plasmid pXC-K expressing only Ela almost totally repressed the expression of pAcatH (compared with $\mathrm{p} \Delta \mathrm{XC}-\mathrm{K}$ lane). When pAcatH was cotransfected with $\mathrm{pXC}$ or $\mathrm{pXC}-\mathrm{H}$, there was a very small amount of CAT expression. However, this level of CAT expression, in three independent assays, ranged within $5-10 \%$ of the level seen in cells that did not express any Ela (lane $\mathrm{p} \Delta \mathrm{XC}-\mathrm{K}$ ) and, therefore, suggests that the Elb 19-kD $T$ antigen does not have a prominent effect (such as observed for the SV40 and Py enhancers) on the release of Ela-mediated repression of the heavychain enhancer in myeloma cells.

\section{Trans-activation is cell type-specific}

Although we have observed trans-activation of gene expression driven by SV40 and Py enhancers in rat fibroblasts (CREF) and in human epithelial cells (HeLa), we did not observe trans-activation of gene expression driven by immunoglobulin heavy-chain enhancer in myeloma cells.

The lack of 19-kD T antigen-mediated trans-activation in the latter case may be due to the cell type or due 


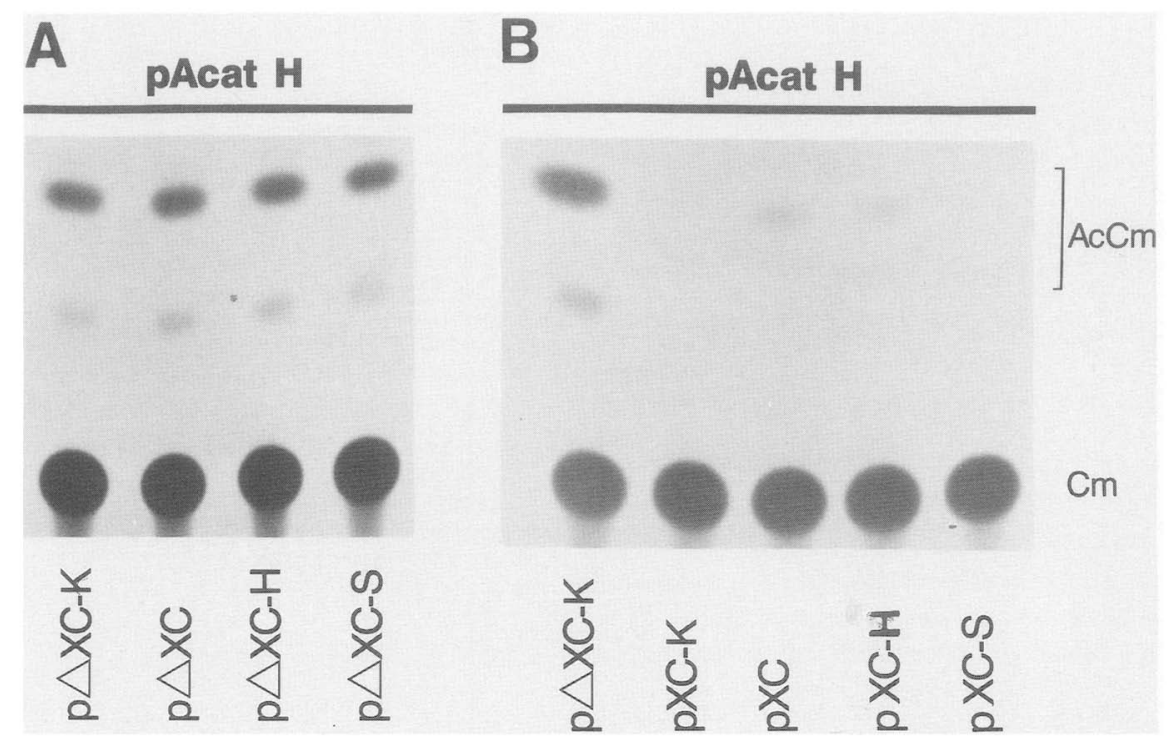

Figure 6. Effect of Elb $(A)$ and Ela plus Elb $(B)$ on pAcatH expression. Mouse myeloma cells (S194, ATCC TIB-19) were transfected with pAcatH $(1 \mu \mathrm{g})$ and the various Ad5 plasmids $(3 \mu \mathrm{g})$ by the DEAE dextran method as described by Garcia et al. (1986), and the CAT activity was determined from extracts prepared 48 or $60 \mathrm{hr}$ after transfection. (AcCm) Acetyl chloramphenicol; (Cm) chloramphenicol.

to the nature of the heavy-chain enhancer sequences. To determine whether the $\mathrm{E} 1 \mathrm{~b}$ trans-activation property is functional in myeloma cells, we examined the effect of $\mathrm{E} 1 \mathrm{~b}$ on $\mathrm{pSV}_{2} \mathrm{CAT}$ expression. It is known that SV40 promoter-enhancer elements are functional in myeloma cells (Banerii et al. 1983). In cells transfected with $\mathrm{pSV}_{2} \mathrm{CAT}$ and $\mathrm{p} \Delta \mathrm{XC}-\mathrm{K}$ there was significant CAT expression (Fig. $7 \mathrm{~A}$ ). In cells transfected with $\mathrm{pSV}_{2} \mathrm{CAT}$ and $\mathrm{p} \Delta \mathrm{XC}-\mathrm{H}$, the level of CAT expression did not increase further, suggesting that the Elb trans-activation function is not apparent in myeloma cells. This conclusion was further substantiated by examining the expression of pAcatH in rat fibroblasts (Fig. 7B). It has been reported that the immunoglobulin enhancer is functional (albeit at reduced levels in the natural orientation) in fibroblasts (Wasylyk and Wasylyk 1986). CREF cells were cotransfected with pAcat $\mathrm{H}$ and $\mathrm{p} \Delta \mathrm{XC}-\mathrm{H}$, and the CAT expression was quantitated (Fig. 7B). Plasmid $\mathrm{p} \Delta \mathrm{XC}-\mathrm{H}$ reproducibly trans-activated $\mathrm{pAcat}-\mathrm{H}$ expression about fivefold, suggesting that $19-\mathrm{kD}$-mediated trans-activation of the IgH enhancer may be regulated by the cell type.

\section{Trans-activation is specific for enhancer}

To determine whether trans-activation by E1b is specific for the SV40 or Py enhancers, we cotransfected a derivative of $\mathrm{pSV}_{2}$ neo lacking the enhancer, $\mathrm{pSV}_{2}$ neo $\Delta \mathrm{E}$, or pG2 (Hen et al. 1986), containing only the rabbit $\beta$ globin promoter, along with the various E1b plasmids, and the expression of neo or $\beta$-globin RNA was analyzed.

As seen in Figure 8A, cells cotransfected with $\mathrm{pSV}_{2}$ neo $\Delta \mathrm{E}$ and $\mathrm{pUC13}$ expressed very low levels of neo RNA. A similar low level of expression was also observed when $\mathrm{pSV}_{2}$ neo $\Delta \mathrm{E}$ was cotransfected with the Elb-defective plasmid $\mathrm{p} \Delta \mathrm{XC}-\mathrm{K}$ or the $19-\mathrm{kD} \mathrm{T}$ antigen- defective plasmid $\mathrm{p} \Delta \mathrm{XC}$-S. Cotransfection of $\mathrm{pSV}_{2}$ neo $\Delta \mathrm{E}$ with $\mathrm{p} \Delta \mathrm{XC}$ (wt $\mathrm{E} 1 \mathrm{~b})$ or $\mathrm{p} \Delta \mathrm{XC}-\mathrm{H}$ (19-kD positive) did not enhance the expression of neo RNA. Similarly, the level of $\beta$-globin expression observed in cells cotransfected with pG2 and pUC13 did not increase when pG2 was cotransfected with the various Elb plasmids. These results reveal that the effect of $\mathrm{E} 1 \mathrm{~b}$ on $\mathrm{pSV}_{2}$ neo and pG2Py observed in the preceding experiments (Fig. 4B and Fig. $5 B$ ) is predominantly due to its effect on the SV40 and Py

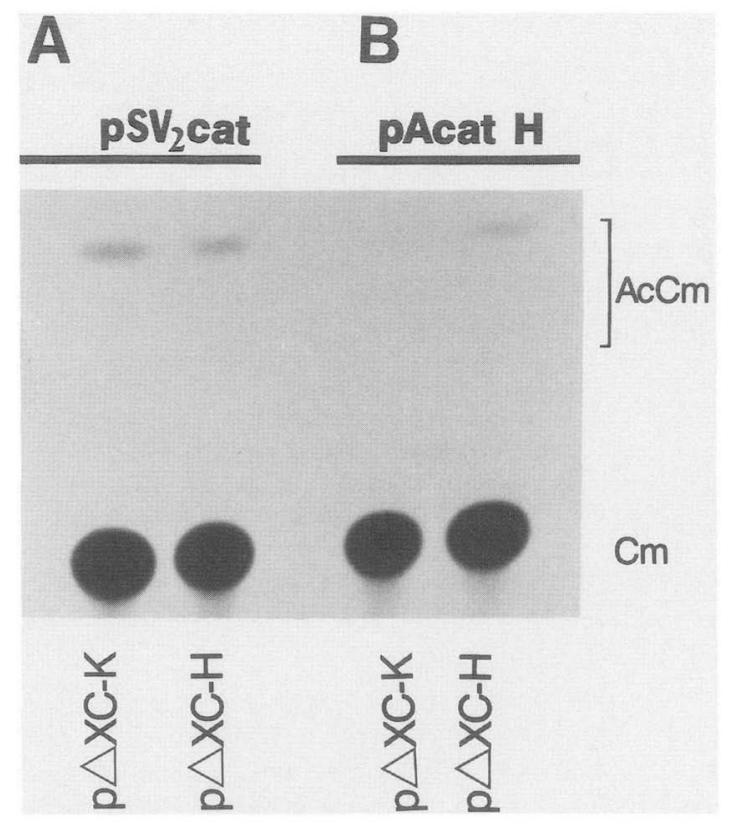

Figure 7. Effect of cell type on trans-activation by Elb. Mouse myeloma $(\mathrm{S} 194)$ cells $(A)$ or rat CREF cells $(B)$ were transfected with $\mathrm{pSV}_{2} \mathrm{CAT}$ and Elb plasmids $(A)$ or pAcatH and Elb plasmids $(B)$ as in Fig. 6 , and CAT activity was determined. 
Yoshida et al.

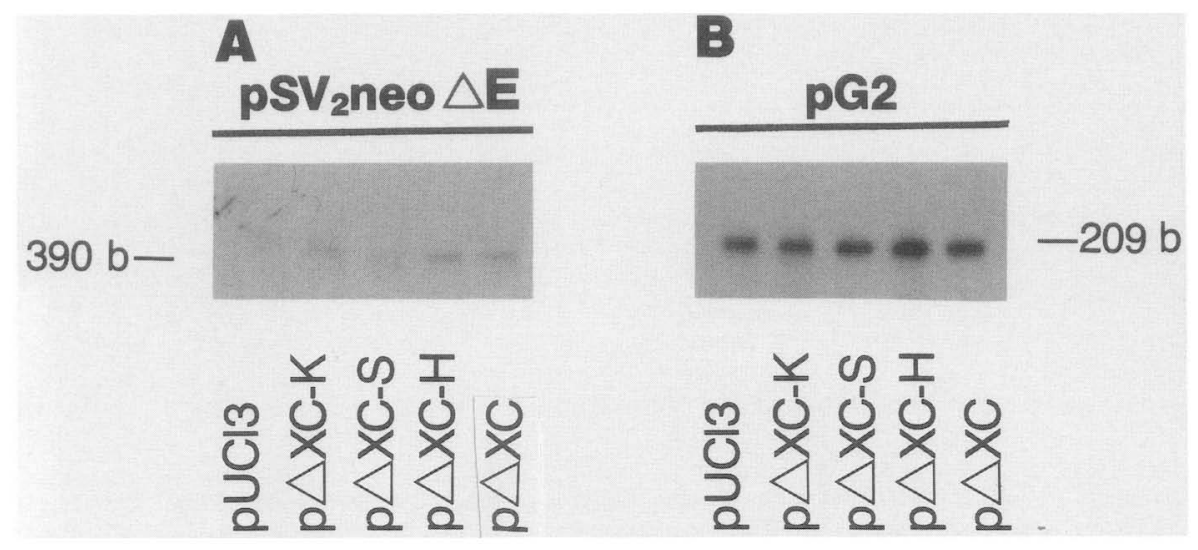

Figure 8. Effect of E1b on enhancerless SV40 early and $\beta$-globin promoters. CREF cells were transfected with $\mathrm{pSV} \mathrm{V}_{2}$ neoDE or pG2 with various Elb plasmids and neo or $\beta$-globin specific RNA was analyzed as described in Figs. 2 and 3.

enhancer elements, respectively. A marginal trans-activation effect for 19-kD on $\mathrm{pG} 2$-driven globin expression (less than twofold; Fig. 5B, lane $\Delta \mathrm{XC}-\mathrm{H}$ ) was not apparent in most other experiments, including those where pG2 was included as an internal control for monitoring transfection efficiencies.
Activation of E1a expression is dependent on the E1a upstream sequences

In the case of Ela, the upstream noncoding sequences have been reported to contain functional enhancer elements (Hearing and Shenk 1983; Hen et al. 1983; Imper-

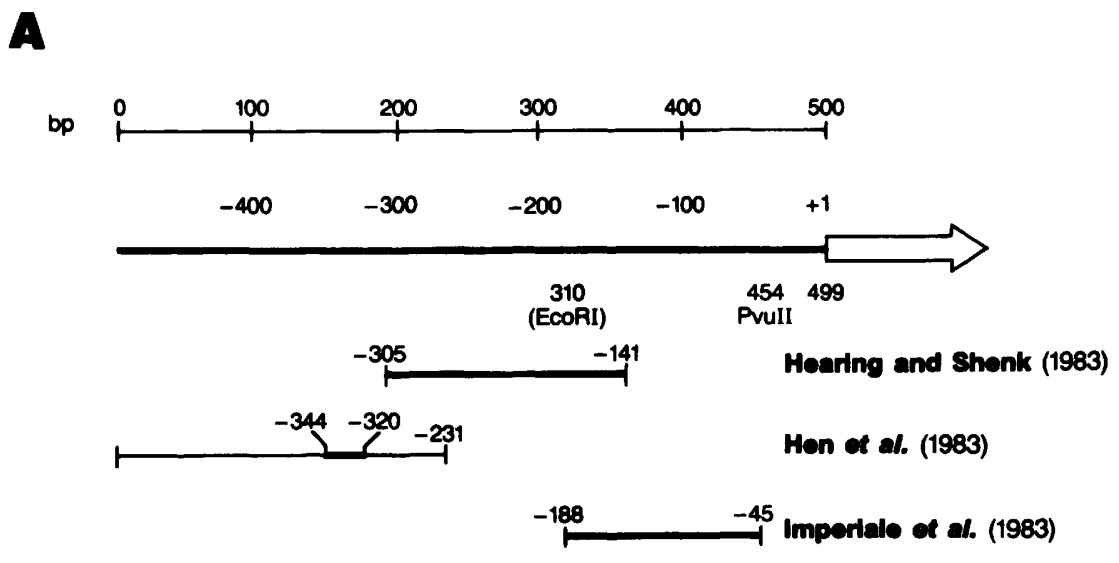

B

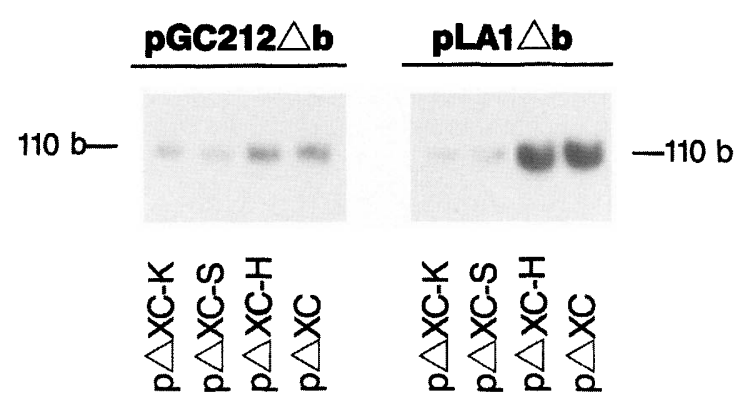

Figure 9. Effect of Ela upstream sequences on Elb trans-activation. $(A)$ Organization of various enhancer elements of Ela. $(B)$ Effect

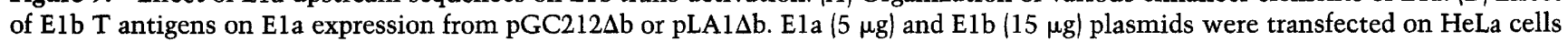
and E1a expression was analyzed as described under Fig. 3. 
iale et al. 1983). However, the elements identified by these three groups are located at different regions as illustrated in Figure 9A. One of the Ad2 plasmids (pGC212) constructed in our laboratory (Chinnadurai 1983) contains a deletion of the left-most $309 \mathrm{bp}$ of the viral genome (see Imperiale et al. 1983). Therefore, the plasmid lacks the enhancer elements identified by Hen et al. (1983) in their entirety and most of the sequences identified by Hearing and Shenk (1983) but retains the element identified by Imperiale et al. (1983). To determine whether the upstream sequences deleted in this plasmid could modulate the effect of Elb on Ela expression observed in our studies (Fig. 3B), a derivative of pGC212 lacking all the E1b coding sequences (pGC212 $\Delta$ b) was cotransfected with various Ad5 Elb plasmids. As seen in Figure 9B, $\mathrm{p} \Delta \mathrm{XC}-\mathrm{K}$ and $\mathrm{p} \Delta \mathrm{XC}-\mathrm{S}$ induced comparable levels of Ela expression from pGC212 $\Delta \mathrm{b}$. In cells transfected with pGC212 $\mathrm{b}$ and $\mathrm{p} \Delta \mathrm{XC}$ or $\mathrm{p} \Delta \mathrm{XC}-\mathrm{H}$ there was a modest increase in Ela expression of about twofold. In these experiments, the Ela expression from an Ela plasmid pLA1 $\Delta b$ that contains the entire upstream noncoding sequences was also compared. As in the case of pGC212 $\Delta \mathrm{b}$, the E1b plasmids $\mathrm{p} \Delta \mathrm{XC}-\mathrm{K}$ and $\mathrm{p} \Delta \mathrm{XC}-\mathrm{S}$ induced more or less similar levels of Ela expression from pLAl $\Delta \mathrm{b}$. However, the Elb plasmids $\mathrm{p} \Delta \mathrm{XC}$ and $\mathrm{p} \Delta \mathrm{XC}-\mathrm{H}$ had a more pronounced effect on Ela expression, resulting in a greater than 15-fold increase (as measured in three independent experiments) in Ela expression, compared to cells that do not express Elb (p $\Delta \mathrm{XC}-\mathrm{K}$ ) or Elb 19-kD T antigen ( $\mathrm{p} \Delta \mathrm{XC}$-S). These results suggest that the effect of Elb on E1a expression is modulated by the upstream enhancercontaining sequences. The modest twofold increase in Ela expression from pGC2 $12 \Delta b$ is probably regulated by the upstream enhancerlike element contained in this plasmid and identified by Imperiale et al. (1983).

\section{Activation of Py enhancer in undifferentiated F9 cells by $E 1 b$}

It has been reported that undifferentiated F9 embryonal carcinoma cells contain an "Ela-like" activity (Imperiale et al. 1984). Consistent with this notion, it has been shown that the Py enhancer is repressed in these cells, whereas a mutant enhancer that is also not repressed by Ela is active (Hen et al. 1986). To determine whether Elb could activate Py enhancer in F9 cells, we cotransfected with pG2Py and various E1b plasmids and analyzed the expression of $\beta$-globin (Fig. 10).

F9 cells transfected with plasmid pG2Py* containing the enhancer mutation (Py ECF 9.1) and pUC13 carrier DNA expressed significant levels of globin RNA, whereas in cells transfected with pG2Py containing wt Py enhancer and carrier pUC13 vector DNA or Elb-defective plasmid $\mathrm{p} \Delta \mathrm{XC}-\mathrm{K}$, the expression of globin was repressed. However, cells cotransfected with $\mathrm{p} \Delta \mathrm{XC}$, containing $w t$ Elb coding sequences, or $\mathrm{p} \Delta \mathrm{XC}-\mathrm{H}$, containing the mutation within the $55-\mathrm{kD} \mathrm{T}$ antigen, expressed globin RNA at levels comparable to that in cells transfected with $\mathrm{pG} 2 \mathrm{Py}^{*}$, indicating that in the presence of the amino-terminal half of $\mathrm{E} 1 \mathrm{~b}$, the wt Py enhancer is

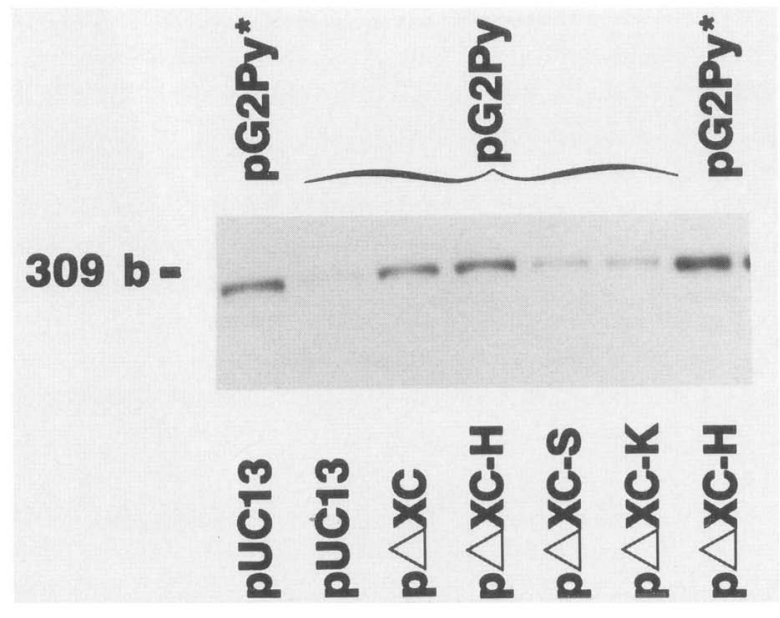

Figure 10. Effect of Elb $\mathrm{T}$ antigens on Py enhancer expression in F9 cells. F9 undifferentiated cells were cotransfected with pG2Py or pG2Py* and the various E1b plasmids by the calcium phosphate method. Total cytoplasmic RNA was extracted $24 \mathrm{hr}$ after transfection and analyzed for $\beta$-globin expression.

not repressed. This release of repression was reproducible in three separate experiments. In cells transfected with pG2Py and the E1b plasmid defective in the 19-kD $\mathrm{T}$ antigen, there was no significant alteration in the extent of repression of pG2Py, suggesting that the $19-\mathrm{kD} \mathrm{T}$ antigen is essential for activation of the Py enhancer in undifferentiated F9 cells.

\section{Discussion}

Trans-activation by $E 1 b$

Our results demonstrate that the early region Elb of Ad5 and Ad2 (group C) and Ad7 (group B) has a trans-activation function, which is especially pronounced on viral and cellular enhancer element (SV40, Py, Ela, and immunoglobulin heavy-chain)-driven promoters. We have localized this trans-activation function within the 19-kD $\mathrm{T}$ antigen coding region since mutations that exclusively map in this region abolish the enhancer activation function whereas plasmids that can only code for the $19-\mathrm{kD} \mathrm{T}$ antigen retain this activity. The $19-\mathrm{kD}$ trans-activation function differs from the well-known E1a function (Berk et al. 1979; Jones and Shenk 1979) and also from a recently identified function encoded by the $\mathrm{E} 4$ region (Goding et al. 1985). The trans-activation functions encoded by E1a and E4 gene products activate the adenovirus early region E2 efficiently, whereas the Elb 19-kD $\mathrm{T}$ antigen is much less efficient in its action on the E2 promoter (K. Yoshida and G. Chinnadurai, unpub1.). Our results indicate that significant amounts of Elb can be expressed without Ela and that this level of Elb expression is sufficient to induce a large effect on the expression of the test genes CAT, neo, $\beta$-globin, and Ela linked to three different promoter elements (SV40, $\beta$-globin, and Ela) driven by the four enhancer elements tested.

We have shown that the trans-activation function me- 
diated by the $19-\mathrm{kD}$ protein is specific for enhancers, since removal of the 72-bp repeats from the SV40 early promoter and of the upstream sequences from the Ela promoter greatly reduces the effect of the $19-\mathrm{kD}$ protein. Similarly, expression of rabbit $\beta$-globin from its own promoter is not altered by $19-\mathrm{kD}$ T antigen but the $\beta$ globin promoter linked to the Py enhancer is trans-activated. The Ela DNA sequences modulating the $19-\mathrm{kD}$ mediated trans-activation of Ela expression also appear to be located primarily within the two Ela enhancer elements (Hearing and Shenk 1983; Hen et al. 1983). Since Ela expression is also stimulated from plasmid pGC212 $\mathrm{b}$, although to a much lesser extent, it is possible that the $19-\mathrm{kD}$ protein may be exerting this limited effect via the enhancer element identified by Imperiale et al. (1983), which is present in pGC212 $\Delta \mathrm{b}$. The various enhancer-promoter test gene combinations that we have utilized appear to respond to $19-\mathrm{kD} \mathrm{T}$ antigen in rat fibroblasts and human HeLa cells. The immunoglobulin heavy-chain enhancer does not seem to be trans-activated by $19-\mathrm{kD}$ protein in mouse myeloma cells. Since the E1b effect was also not observed with SV40 early promoter-enhancer in myeloma cells, although the heavy-chain enhancer appeared to respond to Elb transactivation in CREF fibroblasts, it seems that this $19-\mathrm{kD}$ protein function may be modulated in a cell type-specific manner. This observation suggests that the $19-\mathrm{kD}$ $\mathrm{T}$ antigen may function directly or indirectly by interacting with some cellular factors. It has been demonstrated in a number of instances that enhancer elements display cell type specificity (for review, see Voss et al. 1986), indicating that the enhancer elements interact with some cellular factors.

The $19-\mathrm{kD} \mathrm{T}$ antigen is predominantly localized on the nuclear envelope and in cytoplasmic membrane components (Persson et al. 1982; White et al. 1984) of cells infected or transformed by $\mathrm{Ad} 2$. In addition, biochemical fractionation of Ad2-infected cells has indicated that a significant fraction of this protein is also present in the nucleoplasm (Green et al. 1982). Therefore, it is possible that the $19-\mathrm{kD}$ function may be mediated by direct association with the target DNA or by other, indirect means such as facilitating formation of transcription complexes mediated by enhancers. It is noteworthy that enhancers have been shown to stimulate formation of active transcription complexes (Treisman and Maniatis 1985; Weber and Shaffner 1985). A direct DNA interaction role would be analogous to the E2 trans-activator of BPV1, which has been shown recently to bind directly to enhancers (Androphy et al. 1987; Moskaluk and Bastika 1987). All the enhancer elements [including the Ela enhancer element identified by Hen et al. (1983)] activated by the $19-\mathrm{kD}$ protein contain the so-called enhancer core element GTGG A/T A/T A/ $T$ (Welher et al. 1983) and may therefore constitute a candidate region for DNA-protein interactions.

\section{Effect on enhancer repression}

Our results show that in the presence of the $19-\mathrm{kD} T$ antigen coded by group C (Ad2 or Ad5) and group B (Ad7) adenoviruses, the repression of SV40 and Py and possibly E1a enhancers mediated by Ad2 or Ad5 is not evident. Recently, it has been reported that in cells transfected with plasmid pGC212 (which contains Ad2 E1a and the amino-terminal half of E1b, i.e., the HindIII-G fragment) and an Ad2 major late promoter (MLP) construct linked with the SV40 enhancer, transcription from the MLP is not repressed (Natarajan 1986). However, repression of MLP was observed when the E1b region of pGC212 was mutated, suggesting that in the presence of the $19-\mathrm{kD} \mathrm{T}$ antigen, the SV40 enhancer may not be repressed. Our results suggest that the antirepression effect may be related directly to the trans-activation function of $19-\mathrm{kD}$ protein, since in myeloma cells where there was no significant trans-activation of the immunoglobulin enhancer, Ela-mediated repression was not released efficiently. The 19-kD trans-activation function appears to be dominant over Ela-mediated repression. Despite a large increase in E1a expression in the presence of E1b, there is no significant Ela-mediated repression (see Fig. 3). It has been shown earlier that repression by Ela is manifested in a dose-dependent manner (Borelli et al. 1984). The mechanism of Ela-mediated enhancer repression is not known. The anti-Ela effect of the $19-\mathrm{kD}$ protein may be useful to probe the Ela repression of enhancers.

Our results indicate that Elb has a large effect on the expression of Ela. This effect typically ranged from 15to 25-fold compared with cells transfected with Ela alone. It has been proposed that Ela autoregulates its own expression by enhancer repression (Borelli et al. 1984; Smith et al. 1985; Tibbetts et al. 1986). However, data inconsistent with this model have also been reported (Hearing and Shenk 1985). If Ela indeed autoregulates by enhancer repression, the observed effect of $19-\mathrm{kD}$ protein on $\mathrm{Ela}$ expression may be due to the perturbation of the enhancer repression effect. Alternatively, since we have observed trans-activation of enhancer-driven gene expression by $19-\mathrm{kD} \mathrm{T}$ antigen, the observed effect of E1b on Ela expression could simply be due to the trans-activation by $19-\mathrm{kD}$ T antigen.

We note that a $19-\mathrm{kD}$ role opposite to the one we have observed on Ela expression has been proposed by White et al. (1986). They observed that in the human diploid fibroblast cell line WI-38 (in which adenovirus growth is relatively restricted) infected with Ad2 or Ad5 mutants defective in the $19-\mathrm{kD}$ protein, the early region $\mathrm{E} 2 \mathrm{a}$ is overexpressed. They have proposed that the enhanced expression of E2a is due to elevated levels of E1a expression, suggesting that Ela expression is under negative control by the $19-\mathrm{kD}$ protein. Here again, it is possible that during viral infection, several viral gene products may interact among themselves in a complex manner; alternatively, the effect could be due to the nature of WI-38 cells. We would like to point out that we have observed the trans-activation function not only during transfection of isolated Ela and Elb genes, but also in cell lines that stably express the $19-\mathrm{kD} T$ antigen; therefore, it appears to be an intrinsic property of the protein. 


\section{Enhancer activation in $\mathrm{F} 9$ cells}

Our results indicate that the Py enhancer could be activated in undifferentiated $\mathrm{F} 9$ cells by the $19-\mathrm{kD} \mathrm{T}$ antigen, suggesting that Elb can also efficiently overcome the repression mediated by a cellular gene product. In addition, we have observed trans-activation of Py $\mathrm{mu}$ tant enhancer $\left(\mathrm{Py}^{\star}, \mathrm{Py}\right.$ ECF 9.1) reported not to be repressed by Ela (Hen et al. 1986). It has recently been reported that the activated cellular oncogene T24-c-Ha-ras also activates Py and $\mathrm{Py}^{*}$ enhancers in F9 cells (Wasylyk et al. 1987). These results would imply that activation of the Py enhancer by the $19-\mathrm{kD}$ protein and by T24 ras need not necessarily involve reversal of the repression effect mediated by Ela or the "Ela-like" cellular repressor but may reflect an Ela effect-independent trans-dominant mechanism. However, repression of Py mutant enhancers that are active in F9 cells by Ela has also been observed (Velcich et al. 1986). Therefore, it may be difficult at present to draw definitive conclusions as to whether enhancer activation by $19-\mathrm{kD}$ protein and T24 ras leads to a true reversal of E1a or "E1alike" repression. T24 ras has been reported to activate enhancers in myeloma cells (Wasylyk et al. 1987). However, the $19-\mathrm{kD}$ protein does not trans-activate the SV40 and immunoglobulin heavy-chain enhancer in these cells. In addition, we have also observed in several experiments that T24 ras does not activate the SV40 early promoter in Ela-BRK cells (results not shown), whereas Elb efficiently activates under the same conditions. Although we have not examined the Py enhancer per se in myeloma cells, it would appear from the above two observations that trans-activation by these two transforming genes may involve somewhat different mechanisms. However, it is interesting that these two oncogenes have similar enhancer activation function in F9 cells and also cooperate with Ela in oncogenic conversion of primary rodent cells (Ruley 1983). Protein p21, coded by the ras oncogene, resides on the inner surface of the plasma membrane (Shih and Weeks 1984), and since enhancer activation by T24 ras parallels activation by the tumor promoter TPA, it has been postulated that T24 ras activates previously inactive enhancer factors by phosphorylation via protein kinase $\mathrm{C}$ (Wasylyk et al. 1987). In contrast, the $19-\mathrm{kD} \mathrm{T}$ antigen has a different subcellular localization (i.e., in the nuclear membrane, cytoplasmic membrane, and nucleoplasm), and enhancer activation by this protein may occur by an alternate mechanism.

It should be pointed out that it is also possible that the $19-\mathrm{kD}$ protein may activate the Py enhancer via induction of differentiation-related cellular changes instead of overcoming the effect of the cellular "E1a-like" activity. It has been reported that Py enhancer activity increases during differentiation (Katinka et al. 1981; Sekikawa and Levine 1981; Fuijimura and Linney 1982). It is possible that the $19-\mathrm{kD}$ protein may induce some cellular changes associated with the differentiation of F9 cells, thereby resulting in the activation of the Py enhancer. It is noteworthy that the introduction of cellular oncogenes c-fos (Müller and Wagner 1984) and ras (Weinberg
1984) into F9 cells has been shown to induce differentiation. If the $19-\mathrm{kD} \mathrm{T}$ antigen induces some changes associated with differentiation, it is possible that differentiated F9 cells may contain a "19-kD-like" activity.

\section{Enhancer activation and cell transformation}

A number of studies have indicated that the $19-\mathrm{kD} T$ antigen is important for adenovirus-mediated cell transformation. All the Ad5 and Ad7 plasmid constructs that we have used in the present study have also been tested for transformation activity on BRK cells. These studies have also clearly indicated that the $19-\mathrm{kD} \mathrm{T}$ antigen is essential for transformation (K. Yoshida and G. Chinnadurai, unpubl.). The biochemical function of $19-\mathrm{kD} \mathrm{T}$ antigen in cell transformation remains to be elucidated. Since several viral and cellular oncogenes have been implicated in transcriptional regulation (Kingston et al. 1985), the enhancer activation function of $19-\mathrm{kD} \mathrm{T}$ antigen identified in the present study may also be important for cell transformation. It is possible that the $19-\mathrm{kD}$ $\mathrm{T}$ antigen may activate some dormant cellular genes by enhancer trans-activation and that these Elb-activated cellular genes may directly or indirectly lead to cell transformation. It is interesting that the Ela and E1b genes required for immortalization and transformation have opposite effects on enhancers. The Ela gene represses enhancer-linked promoters and trans-activates enhancerless promoters. The $19-\mathrm{kD} \mathrm{T}$ antigen, on the other hand, trans-activates enhancer-linked promoters and relieves E1a-mediated repression. It is possible that the immortalization step by Ela may require repression of a subset of cellular genes and that the transformation process by $19-\mathrm{kD} T$ antigen may activate a second set of cellular genes or deactivate the E1a-repressed genes.

An alternate mechanism would be that the Elb-mediated enhancer activation may lead to cell transformation by regulating the expression of Ela. It has been reported earlier that Ela-immortalized cells express unusually low amounts of Ela RNA compared to cells transformed by Ela and E1b (van den Elsen et al. 1983). It has also been reported that a high level of Ela expression from a strong mouse metallothionein promoter could lead to full transformation of NIH-3T3 cells (Senear and Lewis 1986). Although it is not known whether high levels of Ela expression could lead to full transformation of BRK and other primary cells, it is possible that the highly pronounced effect of $19-\mathrm{kD} T$ antigen on Ela expression that we have observed could lead to full transformation mediated essentially by Ela. Although both alternatives could be true, more work is needed to elucidate fully the possible relationship between the $19-\mathrm{kD}$ regulatory function and cell transformation.

\section{Materials and methods}

Cells

Rat embryo fibroblast cell line CREF (Fisher et al. 1982) was originally obtained from P. Fisher and was grown in Dulbecco modified MEM (DMEM) containing $5 \%$ fetal calf serum. 
Human HeLa cells were grown in monolayer culture using DMEM containing $10 \%$ fetal calf serum. Baby rat kidney (BRK) cells were prepared from 6-day-old Fisher rats by treatment with collagenase-dispase (Boehringer Mannheim, Biochemicals, Indianapolis, Indiana) and grown in $\alpha$-MEM containing $10 \%$ fetal calf serum. BRK cells were immortalized (Ela-BRK) by transfection of a plasmid, pHpal-E, containing the Ela coding sequences of Ad2. F9 embryonal carcinoma cells were obtained from C. Carlin and maintained in DMEM containing $10 \%$ fetal calf serum. S194 myeloma cells were obtained from American Type Culture Collection and were grown in suspension cultures using DMEM and 10\% horse serum.

\section{Plasmids}

The Ad2 Ela-containing plasmid, pHpaI-E, which contains the left $1569 \mathrm{bp}$ (HpaI-E fragment) of the Ad2 genome cloned at the PstI site of pBR322, was originally obtained from J. Darnell. pXC was constructed by recloning the left-most 5788 bp (XhoIC fragment) of Ad5 from plasmid pBL209 (Babiss et al. 1983) in pUC13. Mutant derivatives of $\mathrm{pXC}$ were constructed by linearizing $\mathrm{pXC}$ with various restriction endonucleases, followed by blunt-ending with T4 DNA polymerase or the Klenow fragment of DNA Poll (Maniatis et al. 1982) and recloning. Mutant plasmid pXC-S contains a 4-bp deletion at the SstI site (N1770), pXC-K contains a 4-bp deletion at the KpnI site (N2048), and pXC-H contains a 4-bp insertion at the HindIII site (N2805). Plasmid $\mathrm{p} \Delta \mathrm{XC}$ and the mutants $\mathrm{p} \Delta \mathrm{XC}-\mathrm{S} \mathrm{p} \Delta \mathrm{XC}-\mathrm{K}$, and $\mathrm{p} \Delta \mathrm{XC}-\mathrm{H}$ were derived from the $\mathrm{pXC}, \mathrm{pXC}-\mathrm{S}, \mathrm{pXC}-\mathrm{K}$, and $\mathrm{pXC}-\mathrm{H}$ plasmids, respectively, by deleting the Ela region up to the $X b a-I$ site (N1340). The Ad7 Elb-containing plasmid pRA was constructed by cloning the RsaI-A fragment (N1431-4024) in pUC13. Mutant plasmids pRA-N and pRA-A contain a 4-bp deletion at the NcoI site (N1600) and a 2-bp insertion at the AccI site (N2178), respectively. The deletion in plasmid pRA-N was introduced by $\mathrm{S} 1$ nuclease treatment. The double-mutant plasmid pRA-NA was constructed by ligating mutated segments from pRA-N and pRA-A. The various Ad5 and Ad7 Elb mutations are illustrated in Figure 1. Plasmids $\mathrm{pSV}_{2}$ neo (Southern and Berg 1982) and $\mathrm{pSV}_{2} \mathrm{CAT}$ (Gorman et al. 1982) were obtained from $P$. Southern and B. Howard, respectively. Plasmids pG2Py, pG2Py*, and pG2 (Hen et al. 1986) were obtained from $\mathrm{P}$. Chambon. Plasmid $\mathrm{pSV}_{2}$ neo $\Delta \mathrm{E}$ was constructed by deleting the enhancer sequences between N126 (NsiI) and N270 (PvuII) of the SV40 genome and by recloning the neo transcription unit in pUC13. Plasmid pGC212 $\Delta$ b was constructed by deleting the Elb sequences (SstI-HindIII) from pGC212 (Chinnadurai 1983). Plasmid pLA1 $\Delta$ b was similarly constructed by deleting the EIb sequences from pLAl ( $\mathrm{Ta}$ manoi and Stillman 1982). Plasmid p19Kpm2022-X was constructed by cloning the Ad2 $19-\mathrm{kD}$ coding region ( $\mathrm{XbaI}$ to $\mathrm{XmnI}$ site) from mutant plasmid pBEpm2022 (Barker and Berk 1987) into a pUCl3 vector carrying the SV40 early poly(A) addition signals.

\section{Transfections}

Plasmid DNAs were introduced into cells for transient expression assays either by the $\mathrm{CaPO}_{4}$ or the DEAE dextran methods. Where appropriate, the enhancerless $\beta$-globin plasmid pG2 was cotransfected as an internal control for normalizing transfection efficiencies. Levels of Elb expression also served as additional controls in most experiments.

\section{Acknowledgments}

This work was supported by research grants CA-33616 and CA-31719 from the National Cancer Institute. We thank A.
Berk, C. Carlin, P. Chambon, B. Howard, P. Jat, J. Nevins, P. Sharp, C. Queen, and C.S.H. Young for various plasmids and cells. K.Y. was supported in part by a Postdoctoral Fellowship from the Japan Society for Promoting Science.

\section{Note added in proof}

Trans-activation of viral and cellular promoters by the 19-kD T antigen has also been observed by C.H. Herrmann, C.V. Déry, and M.B. Mathews (Oncogene, in press).

\section{References}

Anderson, C.W., R.C. Schmitt, E.J. Smart, and B.J. Lewis. 1984. Early region 1B of adenovirus 2 encodes two coterminal proteins of 495 and 155 amino acid residues. J. Virol. 50: 387396.

Androphy, E., D.R. Lowry, and J. Schiller. 1987. Bovine papillomavirus E2 trans-acting gene product binds to specific sites in papillomavirus DNA. Nature 325: 70-73.

Babiss, L.E., C.S.H. Young, P.B. Fisher, and H.S. Ginsberg. 1983. Expression of adenovirus Ela and Elb gene products and the Escherichia coli XGPRT gene in KB cells. J. Virol. 46: 454465.

Babiss, L.E., P.B. Fisher, and H.S. Ginsberg. 1984. Effect on transformation of mutations in the early region $1 \mathrm{~b}$-encoded 21- and 55-kilodalton proteins of adenovirus 5. J. Virol. 52: 389-395.

Banerii, J., L. Olson, and W. Schaffner. 1983. A lymphocyte-specific cellular enhancer is located downstream of the joining region in immunoglobulin heavy chain genes. Cell 33: 729740.

Barker, D.D., and A.J. Berk. 1987. Adenovirus proteins from both $\mathrm{E} 1 \mathrm{~b}$ reading frames are required for transformation of rodent cells by viral infection and DNA transfection. Virology 156: 107-121.

Berk, A.J., F. Lee, T. Harrison, J. Williams, and P.A. Sharp. 1979. Pre-early adenovirus 5 gene product regulates synthesis of early viral messenger RNAs. Cell 17: 935-944.

Bernards, R., M.G.W. de Leeuw, A. Houweling, and A.J. van der Eb. 1986. Role of adenovirus early region $1 B$ tumor antigens in transformation and lytic infection. Virology 150: 126139.

Borrelli, E., R. Hen, and P. Chambon. 1984. Adenovirus-2 E1a products repress enhancer-induced stimulation of transcription. Nature 312: 608-612.

Bos, J.L., L.J. Polder, R. Bernards, P.I. Schrier, P.J. van den Elsen, A.J. van der Eb, and $H$. van Ormant. 1981. The $2.2 \mathrm{~kb} \mathrm{E1b}$ mRNA of human Ad12 and Ad5 codes for two tumor antigens starting at different AUG triplets. Cell 27: 121-131.

Chinnadurai, G. 1983. Adenovirus lp ${ }^{+}$locus codes for the 19-kd tumor antigen that plays an essential role in cell transformation. Cell 33: 759-766.

Colbere-Garapin, F., F. Horodniceanu, P. Kourilsky, and A.C. Garapin. 1981. A new dominant hybrid selective marker for higher eukaryotic cells. J. Mol. Biol. 150: 1-14.

de Villiers, J., and W. Schaffner. 1981. A small segment of polyoma virus DNA enhances the expression of a cloned $\beta$ globin gene over a distance of 1400 base pairs. Nucleic Acids Res. 9: 6251-6264.

Dijkema, R., B.M.M. Dekker, and van Ormondt. 1982. The genome organization of the transforming region of adenovirus type 7. Gene 18: 143-156.

Fisher, P.B., L.E. Babiss, I.B. Weinstein, and H.S. Ginsberg. 1982. Analysis of type 5 adenovirus transformation with a cloned rat embryo cell line (CREF). Proc. Natl. Acad. Sci. 79: $3527-3531$. 
Fujimura, F. and E. Linney. 1982. Polyoma mutants that productively infect $\mathrm{F} 9$ embryonal carcinoma cells do not rescue wild type polyoma in F9 cells. Proc. Natl. Acad. Sci. 79: $1479-1483$.

Garcia, J.V., Lê Thi Bich-Thy, J. Stafford, and C. Queen. 1986. Synergism between immunoglobulin-enhancers and promoters. Nature 322: 383-385.

Goding, C., P.J. Alinot, D. Zajchowski, H. Boeux, and C. Kedinger. 1985. Sequence-specific trans-activation of the adenovirus EIIa early promoter by the viral EIV transcription unit. $E M B O ~ J .4: 1523-1528$.

Gorman, C.M., L.F. Moffat, and B.H. Howard. 1982. Recombinant genomes which express chloramphenicol acetyl-transferase in mammalian cells. Mol. Cell. Biol. 2: 1044-1051.

Green, M., K.H. Brackmann, M.A. Cartas, and T. Matsuo. 1982. Identification and purification of a protein encoded by the human adenovirus type 2 transforming region. $J$. Virol. 42: $30-41$.

Hearing, P. and T. Shenk. 1983. The adenovirus type 5 E1a transcriptional control region contains a duplicated enhancer element. Cell 33: 695-703.

-1985. Sequence-independent autoregulation of the adenovirus type 5 Ela transcription unit. Mol. Cell. Biol. 5: 3214-3221.

Hen, R., E. Borrelli, P. Sassone-Corsi, and P. Chambon. 1983. An enhancer element is located 340 base pairs upstream from the adenovirus-2 E1a gene. Nucleic Acids Res. 11: $8747-8760$.

Hen, R., E. Borrelli, and P. Chambon. 1985. Repression of the immunoglobulin heavy chain enhancer by the adenovirus-2 Ela products. Science 230: 1391-1394.

Hen, R., E. Borrelli, C. Fromental, P. Sassone-Corsi, and P. Chambon. 1986. A mutated polyoma virus enhancer which is active in undifferentiated embryonal carcinoma cells is not repressed by the adenovirus- 2 Ela products. Nature 321: 249-251.

Hurwitz, D.R., and G. Chinnadurai. 1985. Evidence that a second tumor antigen coded by adenovirus early gene region Ela is required for efficient cell transformation. Proc. Natl. Acad. Sci. 82: 163-167.

Imperiale, M.J., L.T. Feldman, and J.R. Nevins. 1983. Activation of gene expression by adenovirus and herpesvirus regulatory genes acting in trans and by a cis-acting adenovirus enhancer element. Cell 35: 127-136.

Imperiale, M.J., H.-T. Kao, T. Feldman, J.R. Nevins, and S. Strickland. 1984. Common control of the heat shock gene and early adenovirus genes: Evidence for a cellular Ela-like activity. Mol. Cell. Biol. 4: 867-874.

Jones, N. and T. Shenk. 1979. An adenovirus type 5 early gene function regulates expression of other early viral genes. Proc. Natl. Acad. Sci. 76: 3665-3669.

Katinka, M., M. Vasseur, N. Montreau, M. Yaniv, and P. Blangy. 1981. Polyoma DNA sequences involved in control of viral gene expression in murine embryonal carcinoma cells. Nature 290: 720-722.

Kimura, G., A. Itagaki, and J. Summers. 1975. Rat cell line 3Y1 and its virogenic polyoma and SV40 transformed derivatives. Int. I. Cancer 15: 694-706.

Kingston, R.E., A.S. Baldwin, and P.A. Sharp. 1985. Transcription control by oncogenes. Cell 41: 3-5.

Laimins, L.A., G. Khoury, C. Gorman, B. Howard, and P. Gruss. 1982. Host specific activation of transcription by tandem repeats from simian virus 40 and a Moloney murine leukemia virus. Proc. Natl. Acad. Sci. 79: 6453-6457.

Logan, J., S. Pilder, and T. Shenk. 1984. Functional analysis of adenovirus type 5 early region 1B. Cancer Cells 2: 527-532.

Mak, I. and S. Mak. 1983. Transformation of rat cells by cyt mutants of adenovirus type 12 and mutants of adenovirus type 5. J. Virol. 45: 1107-1117.

Maniatis, T., E.F. Fritsch, and J. Sambrook. 1982. Molecular cloning: A laboratory manual. Cold Spring Harbor Laboratory, Cold Spring Harbor, New York.

Moskaluk, C. and D. Bastia. 1987. The E2 "gene" of bovine papillomavirus encodes an enhancer-binding protein. Proc. Natl. Acad. Sci. 84: 1215-1218.

Müller, R. and E.F. Wagner. 1984. Differentiation of F9 teratocarcinoma stem cells after transfer of c-fos proto-oncogenes. Nature 311: 438-442.

Natarajan, V. 1986. Adenovirus Ela and Elb gene products regulate enhancer mediated transcription. Nucleic Acids Res. 14: 9445-9456.

Nevins, J.R. 1981. Mechanism of activation of early viral transcription by the adenovirus E1a gene product. Cell 26: 213220.

Persson, H., M.G. Katze, and L. Philipson. 1982. Purification of a native membrane-associated adenovirus tumor antigen. $/$. Virol. 42: 905-961.

Ruley, H.E. 1983. Adenovirus early region $1 \mathrm{~A}$ enables viral and cellular transforming genes to transform primary cells in culture. Nature 300: 149-152.

Sekikawa, K. and A.J. Levine. 1981. Isolation and characterization of polyoma host-range mutants that replicate in nullipotential embryonal carcinoma cells. Proc. Natl. Acad. Sci. 78: $110-1104$.

Senear, A.W. and J.B. Lewis. 1986. Morphological transformation of established rodent cell lines by high-level expression of the adenovirus type 2 Ela gene. Mol. Cell. Biol. 6: 12531260.

Shih, T.Y. and M.O. Weeks. 1984. Oncogenes and cancer: p21 ras genes. Cancer Invest. 2: 109-123.

Smith, D.H., D.M. Kegler, and E. Ziff. 1985. Vector expression of adenovirus type $5 \mathrm{E}$ la proteins: Evidence for Ela autoregulation. Mol. Cell. Biol. 5: 2684-2696.

Solnick, D. and M.A. Anderson. 1982. Transformation-defective adenovirus mutant defective in expression of region $1 \mathrm{~A}$ but not 1B. J. Virol. 42:106-113.

Southern, P.J. and P. Berg. 1982. Transformation of mammalian cells to antibiotic resistance with a bacterial gene under control of the SV40 early region promoter. J. Mol. Appl. Gen. 1: 327-341.

Stein, R.W. and E.B. Ziff. 1987. Repression of insulin gene expression by adenovirus type $5 \mathrm{Ela}$ proteins. Mol. Cell. Biol. 7: $1164-1170$.

Subramanian, T., M. Kuppuswamy, S. Mak, and G. Chinnadurai. 1984. Adenovirus $c y t^{+}$locus, which controls cell transformation and tumorigenicity, is an allele of $l p^{+}$locus, which codes for a 19-kilodalton tumor antigen. $J$. Virol. 52: 336-343.

Sussenbach, J.S. 1984. The structure of the genome. In The adenoviruses, (ed. H.S. Ginsberg), pp. 35-124. Plenum Press, New York.

Takemori, N., C. Cladaras, B. Bhat, A.J. Conley, and W.S.M. Wold. 1984. cyt gene of adenovirus 2 and 5 is an oncogene for transforming function in early region E1B and encodes the E1B 19,000-molecular-weight polypeptide. I. Virol. 52: 793-805.

Tamanoi, F. and B.W. Stillman. 1982. Functions of adenovirus terminal protein in the initiation of DNA replication. Proc. Natl. Acad. Sci. 79: 2221-2225.

Tibbetts, C., P. Larson, and S.N. Jones. 1986. Autoregulation of adenovirus Ela gene expression. J. Virol. 57: 1055-1064.

Treisman, R. and T. Maniatis. 1985. Simian virus 40 enhancer increases the number of RNA polymerase II molecules on linked DNA. Nature 315: 72-75. 
van den Elsen, P.J., A. Houweling, and A.J. van der Eb. 1983. Morphological transformation of human adenoviruses is determined to a large extent by gene products of region Ela. Virology 131: 242-246.

Velcich, A. and E. Ziff. 1985. Adenovirus E1a proteins repress transcription from the SV40 early promoter. Cell 40: 705716.

Velcich, A., F.G. Kern, C. Basilico, and E.B. Ziff. 1986. Adenovirus $E 1$ a proteins repress expression from polyoma virus early and late promoters. Mol. Cell. Biol. 6: 4019-4025.

Virtanen, A. and U. Pettersson. 1985. Organization of early region $1 \mathrm{~B}$ of human adenovirus type 2: Identification of four differentially spliced mRNAs. J. Virol. 54: 383-391.

Voss, S.D., U. Schlokat, and P. Gruss. 1986. The role of enhancers in the regulation of cell-type-specific transcriptional control. Trends Biochem. Sci. 11: 287-289.

Wasylyk, C. and B. Wasylyk. 1986. The immunoglobulin heavy-chain B-lymphocyte enhancer efficiently stimulates transcription in non-lymphoid cells. EMBO $/$. 5: 553-560.

Wasylyk, C., J.L. Imler, J. Perez-Mutul, and B. Wasylyk. 1987. The c-Ha-ras oncogene and a tumor promoter activate the polyoma virus enhancer. Cell 48: 525-534.

Weber, F. and W. Schaffner. 1985. Simian virus 40 enhancer increases RNA polymerase density with the linked gene. $\mathrm{Na}$ ture 315: 75-77.

Weinberg, R.A. 1984. Cellular oncogenes. Trends Biochem. Sci. 9: $131-133$.

Weiher, H., M. Konig, and P. Gruss. 1983. Multiple point mutations affecting the simian virus 40 enhancer. Science 219: 626-631.

White, E., S.H. Blose, and B.W. Stillman. 1984. Nuclear envelope localization of an adenovirus tumor antigen maintains the integrity of cellular DNA. Mol. Cell. Biol. 4: 28652875.

White, E., B. Faha, and B. Stillman. 1986. Regulation of adenovirus gene expression in human WI38 cells by an E1B-encoded tumor antigen. Mol. Cell. Biol. 6: 3763-3773.

Wigler, M., R. Sweet, G.K. Sim, B. Wold, A. Pellicer, E. Lacy, T. Maniatis, S. Silverstein, and R. Axel. 1979. Transformation of mammalian cells with genes from prokaryotes and eukaryotes. Cell 16: 777-785. 


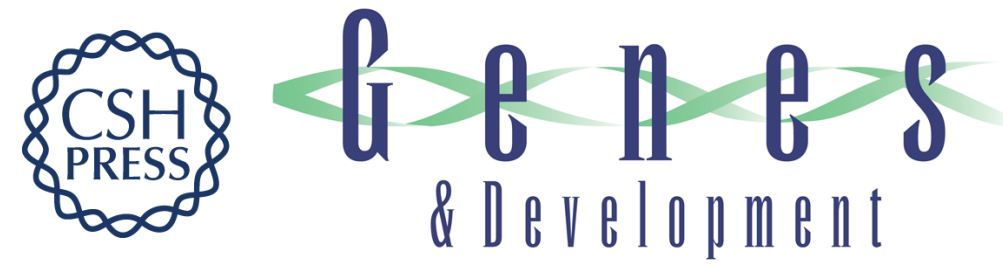

\section{Adenovirus transforming 19-kD T antigen has an enhancer-dependent trans-activation function and relieves enhancer repression mediated by viral and cellular genes.}

K Yoshida, L Venkatesh, M Kuppuswamy, et al.

Genes Dev. 1987, 1:

Access the most recent version at doi:10.1101/gad.1.7.645

References This article cites 66 articles, 30 of which can be accessed free at:

http://genesdev.cshlp.org/content/1/7/645.full.html\#ref-list-1

License

Email Alerting Receive free email alerts when new articles cite this article - sign up in the box at the top

Service right corner of the article or click here.

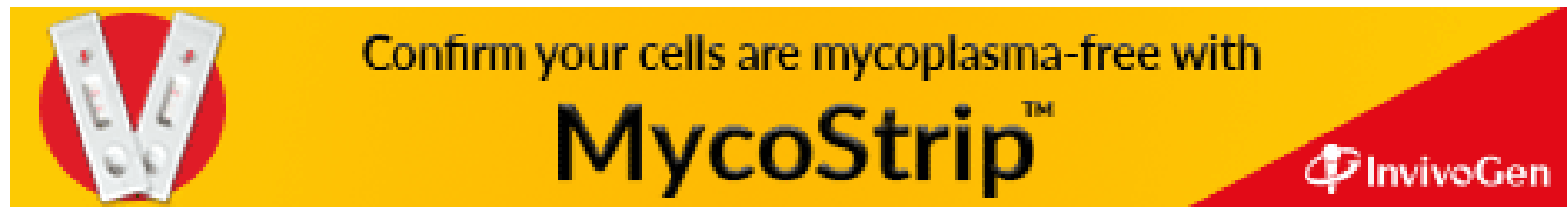

